\title{
Formation of iodo-trihalomethanes, iodo-acetic acids, and iodo-acetamides during chloramination of iodide-containing waters: Factors influencing formation and reaction pathways
}

\author{
Shaogang Liu ${ }^{\mathrm{a}, \mathrm{b}}$, Zhenlin Li ${ }^{\mathrm{b}}$, Huiyu Dong ${ }^{\mathrm{a}}$, Bernard A. Goodman ${ }^{\mathrm{c}}$, Zhimin Qiang ${ }^{\mathrm{a}, *}$ \\ a Key Laboratory of Drinking Water Science and Technology, Research Center for Eco-Environmental Sciences, University of Chinese Academy of Sciences, \\ Chinese Academy of Sciences, 18 Shuang-qing Road, Beijing, 100085, China \\ ${ }^{\mathrm{b}}$ Guangxi Colleges and Universities Key Laboratory of Food Safety and Pharmaceutical Analytical Chemistry, Guangxi Key Laboratory of Chemistry and \\ Engineering of Forest Products, School of Chemistry and Chemical Engineering, Guangxi University for Nationalities, Nanning, 530006, Guangxi, China \\ ${ }^{c}$ College of Physical Science and Engineering, State Key Laboratory for Conservation and Utilization of Subtropical Agro-Bioresources, Guangxi University, \\ Nanning, 520004, Guangxi, China
}

\section{H I G H L I G H T S}

- Kinetic model for $\mathrm{HOI} / \mathrm{I}_{2}$ evolution during chloramination was developed.

- Maximum I-DBPs formation and $\mathrm{HOI} / \mathrm{I}_{2}$ consumption occurred at $\mathrm{pH}$ 8.0.

- I-HAcAms, once formed, could be further hydrolyzed to corresponding I-HAAs.

- Low-SUVA 254 NOM favored I-DBPs formation compared to high-SUVA 254 NOM.

- Reaction pathways for I-DBPs formation during chloramination were proposed.

\section{A R T I C L E I N F O}

\section{Article history:}

Received 3 June 2016

Received in revised form 27 August 2016

Accepted 29 August 2016

Available online 30 August 2016

\section{Keywords:}

Iodinated disinfection by-products (I-DBPs)

Monochloramine $\left(\mathrm{NH}_{2} \mathrm{Cl}\right)$

Natural organic matter (NOM)

Influential factors

Pathways
G R A P H I C A L A B S T R A C T

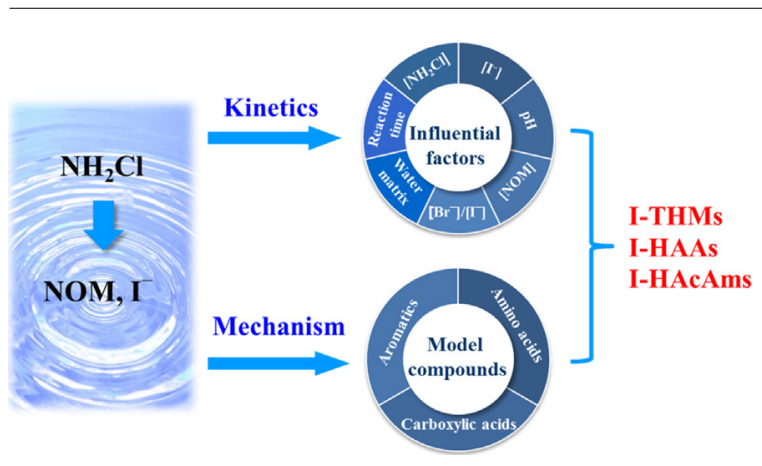

\section{A B S T R A C T}

This study investigated systematically the factors influencing the formation of iodinated disinfection by-products (I-DBPs) during chloramination of $\mathrm{I}^{-}$-containing waters, including reaction time, $\mathrm{NH}_{2} \mathrm{Cl}$ dose, $\mathrm{I}^{-}$concentration, $\mathrm{pH}$, natural organic matter (NOM) concentration, $\mathrm{Br}^{-} / \mathrm{I}^{-}$molar ratio, and water matrix. Among the I-DBPs detected, iodoform $\left(\mathrm{CHI}_{3}\right)$, iodoacetic acid (IAA), diiodoacetic acid (DIAA), triiodoacetic acid (TIAA), and diiodoacetamide (DIAcAm) were the major species produced from reactions between reactive iodine species $\left(\mathrm{HOI} / \mathrm{I}_{2}\right)$ and NOM. A kinetic model involving the reactions of $\mathrm{NH}_{2} \mathrm{Cl}$ auto-decomposition, iodine species transformation and NOM consumption was developed, which could well describe $\mathrm{NH}_{2} \mathrm{Cl}$ decay and $\mathrm{HOI} / \mathrm{I}_{2}$ evolution. Higher concentrations of $\mathrm{CHI}_{3}$, IAA, DIAA, TIAA, and DIAcAm were observed in chloramination than in chlorination, whereas $\mathrm{IO}_{3}{ }^{-}$was only formed significantly in chlorination. Maximum formation of I-DBPs occurred at pH 8.0, but acidic conditions favored the formation of iodinated haloacetic acids and DIAcAm. Increasing $\mathrm{Br}^{-} / \mathrm{I}^{-}$molar ratio from 1 to 10 did not increase the total amount of I-DBPs, but produced more bromine-substituting species. In addition, chloramination of 18 model compounds indicated that

\footnotetext{
* Corresponding author.

E-mail address: qiangz@rcees.ac.cn (Z. Qiang).
} 
low-SUVA 254 (specific ultraviolet absorbance at $254 \mathrm{~nm}$ ) NOM generally favored the formation of I-DBPs compared to high-SUVA 254 NOM. Finally, potential pathways for I-DBPs formation from chloramination of NOM were proposed.

(C) 2016 Elsevier B.V. All rights reserved.

\section{Introduction}

The formation of disinfection by-products (DBPs) during water treatment is of great concern because of their potential adverse health effects. To comply with the increasingly stringent regulatory limits for trihalomethanes (THMs) and haloacetic acids (HAAs) [1], many water utilities have switched from free chlorine to monochloramine $\left(\mathrm{NH}_{2} \mathrm{Cl}\right)$ as a secondary disinfectant, because the latter leads to lower concentrations of regulated THMs and HAAs. However, the use of $\mathrm{NH}_{2} \mathrm{Cl}$ can promote the formation of a large number of other potentially harmful DBPs, such as haloacetonitriles (HANs), $\mathrm{N}$-nitrosodimethylamine, and iodinated disinfection by-products (I-DBPs) [2,3]. Therefore, DBPs formation can still be problematic during chloramination of drinking water.

During the disinfection processes, iodide $\left(\mathrm{I}^{-}\right)$in source waters is rapidly oxidized to hypoiodous acid (HOI), which can either react with natural organic matter (NOM) to form various I-DBPs, or be further oxidized to iodate $\left(\mathrm{IO}_{3}{ }^{-}\right)$[4-6]. Apart from iodinated trihalomethanes (I-THMs) [7], many other I-DBPs have also been found in disinfected drinking water in recent years, including iodinated haloacetic acids (I-HAAs) [2], polar I-DBPs [8], and iodinated haloacetamides (I-HAcAms) [9]. The I-DBPs are generally more toxic than their chlorinated and brominated analogues [10], and recent mammalian cell toxicity results have shown that iodoform $\left(\mathrm{CHI}_{3}\right)$ is 60 and 146 times more cytotoxic than bromoform $\left(\mathrm{CHBr}_{3}\right)$ and chloroform $\left(\mathrm{CHCl}_{3}\right)$, respectively [11,12]. I-HAAs are frequently found in chloraminated water, which represent a new class of highly toxic DBPs in drinking water [2,13]. In addition, new nitrogenous I-DBPs, such as I-HAcAms [e.g., chloroiodoacetamide (CIIAcAm), diiodoacetamide(DIAcAm), and iodoacetamide (IAcAm)], are believed to be more toxic than their carbonaceous analogues [14]. By comparing the I-DBPs formed in oxidative treatments of $\mathrm{I}^{-}$-containing waters using chlorine [8,15-17], $\mathrm{NH}_{2} \mathrm{Cl}$ $[3,7]$, chlorine dioxide [18,19], ozone [20], and potassium permanganate [21], it turns out that $\mathrm{NH}_{2} \mathrm{Cl}$ favors the formation of I-DBPs $[4,22,23]$. However, most previous studies on I-DBPs in drinking water have only focused on I-THMs, while little is known about the formation and speciation of I-HAAs and I-HAcAms during chloramination.

In this study, we systematically investigated the factors influencing the formation of three typical classes of I-DBPs (i.e., I-THMs, I-HAAs, and I-HAcAms) during chloramination of $\mathrm{I}^{-}$-containing waters, including reaction time, $\mathrm{NH}_{2} \mathrm{Cl}$ dose, $\mathrm{I}^{-}$concentration, $\mathrm{pH}$, NOM concentration, $\mathrm{Br}^{-} / \mathrm{I}^{-}$molar ratio, and water matrix. A kinetic model, which involved the reactions of $\mathrm{NH}_{2} \mathrm{Cl}$ auto-decomposition, iodine species transformation and NOM consumption, was developed to describe $\mathrm{NH}_{2} \mathrm{Cl}$ decay and $\mathrm{HOI} / \mathrm{I}_{2}$ evolution. Moreover, 18 model compounds (i.e., amino acids, carboxylic acids, and aromatic compounds) were chloraminated to help clarify the reaction mechanisms for I-DBPs formation.

\section{Materials and methods}

\subsection{Chemicals}

All chemicals were of the highest purity available. Individual I-THMs including bromodiiodomethane $\left(\mathrm{CHBrI}_{2}\right)$, bro- mochloroiodomethane ( $\mathrm{CHBrClI})$, chlorodiiodomethane $\left(\mathrm{CHClI}_{2}\right)$, dibromoiodomethane $\left(\mathrm{CHBr}_{2} \mathrm{I}\right)$ and dichloroiodomethane $\left(\mathrm{CHCl}_{2} \mathrm{I}\right)$, I-HAAs including bromoiodoacetic acid (BrIAA), chloroiodoacetic acid (CIIAA), diiodoacetic acid (DIAA) and iodoacetic acid (IAA), and I-HAcAms including bromoiodoacetamide (BrIAcAm), ClIAcAm, DIAcAm and IAcAm were all purchased from CanSyn Chem. Co. (New Westminister, BC, Canada). A standard mixture of four regulated THMs [THM4, including bromodichloromethane $\left(\mathrm{CHCl}_{2} \mathrm{Br}\right)$, $\mathrm{CHBr}_{3}, \mathrm{CHCl}_{3}$ and dibromochloromethane $\left.\left(\mathrm{CHClBr}_{2}\right)\right]$ and an internal standard of 1,2-dibromopropane were purchased from $\mathrm{J} \& \mathrm{~K}$ Chemical Co. (Beijing, China). $\mathrm{CHI}_{3}$ (99\%), dichloroacetamide (DClAcAm, 99\%), dichloroacetonitrile (DClAN, 99\%), iodoacetonitrile (IAN, 99\%), o-iodophenol (99.8\%), p-iodophenol (99.8\%) and triiodoacetic acid (TIAA, 90\%) were obtained from Sigma Aldrich (St. Louis, MO, USA). Suwannee River NOM isolate (2R101N) was obtained from the International Humic Substances Society. Ammonium sulfate (99\%), potassium bromide (99\%), potassium iodide (99\%) and $\mathrm{NaOCl}$ (5\% of active chlorine) were obtained from Sinopharm Chemical Reagent Co. (Shanghai, China). In addition, 18 model compounds (Sinopharm Chemical Reagent Co.) were used to mimic the reactivity of a variety of NOM moieties during disinfection, whose chemical structures and molecular formulae are listed in Table S1. All reaction solutions were prepared with ultrapure water produced by a Milli-Q system (Advantage A10, Millipore, Billerica, MA, USA).

\subsection{Experimental procedures}

The formation of I-DBPs during chloramination of $\mathrm{I}^{-}$-containing waters was studied as a function of reaction time, $\mathrm{NH}_{2} \mathrm{Cl}$ dose, $\mathrm{I}^{-}$concentration, $\mathrm{pH}$, NOM concentration, $\mathrm{Br}^{-} / \mathrm{I}^{-}$molar ratio, and water matrix. All experiments were performed in triplicate using 40-mL amber glass bottles with polytetrafluoroethylene-lined septum screw-caps under headspace-free conditions. The $\mathrm{pH}$ of all reaction solutions was controlled at $7.0 \pm 0.1$ with $5 \mathrm{mM}$ phosphate buffer except when the effect of $\mathrm{pH}$ was examined. Prior to each experiment, preformed $\mathrm{NH}_{2} \mathrm{Cl}$ solution was freshly prepared by adding a desired amount of $\mathrm{NaOCl}$ stock solution to an $\left(\mathrm{NH}_{4}\right)_{2} \mathrm{SO}_{4}$ solution ( $10 \mathrm{mM}$ bicarbonate buffer, $\mathrm{pH} 8.5)$ at a $\mathrm{Cl} / \mathrm{N}$ molar ratio of 0.7:1 according to previously published procedures [24]. For comparison, a set of experiments using free chlorine was also conducted under the same conditions. Similar experimental procedures were adopted when testing the formation of I-DBPs during chloramination of the model compounds. After certain reaction times, water samples were withdrawn and added to an acidified sulfite solution $\left(\left[\mathrm{HSO}_{3}{ }^{-}\right]:\left[\mathrm{NH}_{2} \mathrm{Cl}\right]\right.$ molar ratio $\left.=1.5\right)$ to quench the residual oxidant. To prevent potential hydrolytic loss of byproducts during storage, water samples were extracted immediately after quenching.

\subsection{Analytical methods}

Reactive iodine species (i.e., $\mathrm{HOI} / \mathrm{I}_{2}$ ) in aqueous solutions were quenched with an excess of phenol and then analyzed as iodophenols by high-performance liquid chromatography (HPLC) as previously described [5]. Dissolved organic carbon (DOC) concentration was measured with a TOC-VCPN analyzer (Shimadzu, Japan). $\mathrm{Br}^{-}, \mathrm{I}^{-}$, and $\mathrm{IO}_{3}^{-}$concentrations were analyzed by an 
Table 1

Main characteristics of three real waters.

\begin{tabular}{|c|c|c|c|c|c|}
\hline Real water & $\mathrm{DOC}(\mathrm{mg} / \mathrm{L})$ & $\mathrm{UV}_{254}(1 / \mathrm{cm})$ & $\mathrm{SUVA}_{254}{ }^{\mathrm{a}}[\mathrm{L} /(\mathrm{mg} \cdot \mathrm{m})]$ & $\mathrm{Br}^{-}(\mu \mathrm{g} / \mathrm{L})$ & $\mathrm{I}^{-}(\mu \mathrm{g} / \mathrm{L})$ \\
\hline WTP & 2.6 & 0.021 & 0.81 & 27.5 & $\mathrm{ND}^{\mathrm{b}}$ \\
\hline MYW & 4.2 & 0.060 & 1.43 & 60.2 & ND \\
\hline WWTP & 5.8 & 0.107 & 1.84 & 100.5 & ND \\
\hline
\end{tabular}

a $\mathrm{SUVA}_{254}=\mathrm{UV}_{254} \times 100 / \mathrm{DOC}$.

b ND: not detected.

ICS-3000 ion chromatograph (Dionex, USA) equipped with an AS19-HC anion separation column. The limits of quantification (LOQs) for $\mathrm{Br}^{-}, \mathrm{I}^{-}$and $\mathrm{IO}_{3}{ }^{-}$were all about $10 \mu \mathrm{g} / \mathrm{L}$. $\mathrm{NH}_{2} \mathrm{Cl}$ concentration was measured using the $\mathrm{N}, \mathrm{N}$-diethyl-p-phenylenediamine (DPD) method [25]. Prior to analysis, free chlorine in chloraminated samples was quenched with an excess of phenol, because the presence of free chlorine causes interference with the DPD method. I-THMs and I-HAAs were quantified according to USEPA Methods 551.1 and 552.2 with minor modifications, respectively. ITHMs were analyzed using a gas chromatograph (Thermo-electron Finnigan, Waltham, MA, USA) equipped with an electron capture detector (ECD) and an HP-5MS column $(30 \mathrm{~m} \times 0.25 \mathrm{~mm}$, $0.25 \mu \mathrm{m}$ film thickness, Agilent Technologies, USA). I-HAAs were analyzed by liquid/liquid extraction with methyl-tert-butyl-ether (MtBE), derivatization with acidified methanol, and quantification by GC/ECD with the same capillary column. I-HAcAms were determined by ultra-high performance liquid chromatography-tandem mass spectrometry (UPLC-MS/MS, Waters, USA) as previously described [9]. The LOQs were in the range of $0.1-1.0 \mu \mathrm{g} / \mathrm{L}$ for ITHMs and I-HAAs, and $0.02-0.04 \mu \mathrm{g} / \mathrm{L}$ for I-HAcAms (Table S2). Other byproducts formed in the reactions between $\mathrm{NOM}$ and $\mathrm{NH}_{2} \mathrm{Cl}$ were identified by triple quadrupole gas chromatography-tandem mass spectrometry (GC-MS/MS, Bruker, Fremont, CA, USA), and their chemical structures were determined by referring to the mass spectral database of National Institute of Standards and Technology.

\subsection{Formation of I-DBPs in real waters}

To evaluate the effect of water matrix on I-DBPs formation during chloramination, $200 \mu \mathrm{g} / \mathrm{L} \mathrm{I}^{-}$was spiked into three real waters including the surface water from Miyun reservoir (MYR), activated carbon-filtered water from Beijing No. 9 drinking water treatment plant (WTP), and secondary effluent from Qinghe wastewater treatment plant (WWTP), whose major quality parameters are summarized in Table 1 . These water samples were filtered through $0.45-\mu \mathrm{m}$ membranes and stored at $4{ }^{\circ} \mathrm{C}$ until use.

\section{Results and discussion}

\subsection{Evolution of reactive iodine species during chloramination}

To understand iodide transformation during chloramination of $\mathrm{I}^{-}$-containing waters, it is essential to assess the evolution of $\mathrm{HOI} / \mathrm{I}_{2}$. Fig. 1 shows the time-dependent changes of $\mathrm{HOI} / \mathrm{I}_{2}$ concentration during chloramination at $\mathrm{pH} 7.0$ for various initial $\mathrm{I}^{-}$concentrations $(10-100 \mu \mathrm{M})$. As expected, increasing the initial $\mathrm{I}^{-}$concentration could significantly enhance the formation of $\mathrm{HOI} / \mathrm{I}_{2}$. Meanwhile, the inset in Fig. 1 shows $\mathrm{HOI} / \mathrm{I}_{2}$ evolution along with $\mathrm{NH}_{2} \mathrm{Cl}$ decay as a function of reaction time at an initial $\mathrm{I}^{-}$concentration of $100 \mu \mathrm{M} . \mathrm{HOI} / \mathrm{I}_{2}$ were produced quickly, reaching a maximum of $56 \mu \mathrm{M}$ at $1 \mathrm{~min}$, and then decreased gradually. The $\mathrm{NH}_{2} \mathrm{Cl}$ concentration decreased rapidly within the first $15 \mathrm{~min}$, and thereafter decreased slowly. It is known that $\mathrm{NH}_{2} \mathrm{Cl}$ can quickly oxidize $\mathrm{I}^{-}$to $\mathrm{HOI} / \mathrm{I}_{2}$, but cannot further oxidize $\mathrm{HOI} / \mathrm{I}_{2}$ to $\mathrm{IO}_{3}{ }^{-}$. However, $\mathrm{HOI}$ can be oxidized to $\mathrm{IO}_{3}{ }^{-}$by free chlorine and free bromine, which have a higher oxidation potential than $\mathrm{NH}_{2} \mathrm{Cl}[4,15]$. Consequently, the

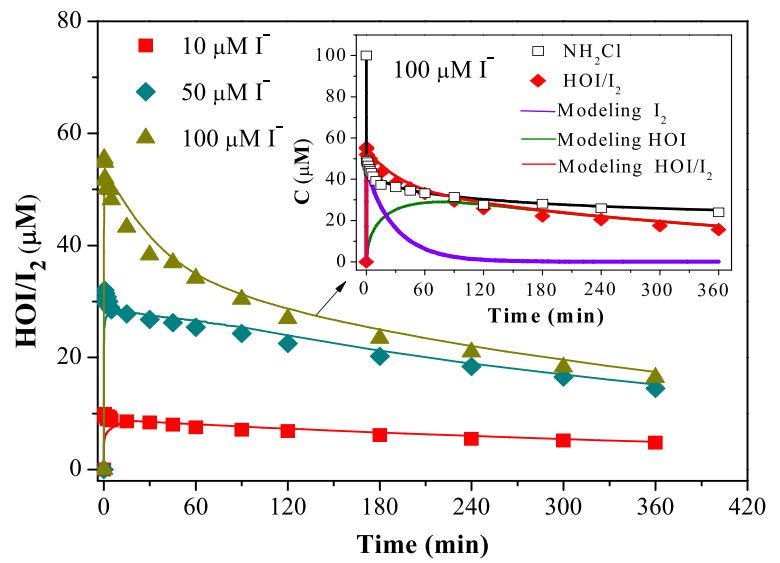

Fig. 1. Measured and modeled evolutions of reactive iodine species $\left(\mathrm{HOI} / \mathrm{I}_{2}\right)$ as a function of reaction time and initial $\mathrm{I}^{-}$concentration during chloramination. Experimental conditions: $\left[\mathrm{NH}_{2} \mathrm{Cl}\right]_{0}=100 \mu \mathrm{M},[\mathrm{DOC}]_{0}=3.0 \mathrm{mg} / \mathrm{L}, 5 \mathrm{mM}$ phosphate buffer $\mathrm{pH} 7.0,25^{\circ} \mathrm{C}$. Symbols and curves represent experimental data and model predictions, respectively.

formation of $\mathrm{IO}_{3}{ }^{-}$, which can only result from the disproportion of HOI during chloramination, is much lower than that during chlorination. Hence, $\mathrm{IO}_{3}{ }^{-}$was not detected in the reaction solution, and $\mathrm{HOI} / \mathrm{I}_{2}$ were the major reactive iodine species.

A kinetic model was developed based on the Kintecus software [26], which could fit well the experimental data using a set of reactions listed in Table $\mathrm{S} 3$ (i.e., $\mathrm{NH}_{2} \mathrm{Cl}$ auto-decomposition, iodine species transformation, and NOM consumption), as shown in Figs. S1 and S2. Previous studies have shown that the second-order rate constants for the reaction of NOM with HOI and $\mathrm{I}_{2}$ were in the ranges of $0.1-0.4 \mathrm{M}^{-1} \mathrm{~s}^{-1}$ and $(0.4-1.5) \times 10^{-4} \mathrm{M}^{-1} \mathrm{~s}^{-1}$, respectively $[5,27]$, which thus accounts for the rapid decrease in $\mathrm{HOI} / \mathrm{I}_{2}$ after $1 \mathrm{~min}$ (Fig. 1). Although HOI may be disproportionated to $\mathrm{I}^{-}$ and $\mathrm{IO}_{3}{ }^{-}[5]$, it could react much faster with NOM, so little $\mathrm{IO}_{3}{ }^{-}$ was detected in the reaction solution.

\subsection{Evolution of I-DBPs during chloramination and chlorination}

Fig. 2a and b compare the evolution of I-DBPs during chloramination and chlorination of $\mathrm{I}^{-}$-containing waters. The formation of $\mathrm{CHI}_{3}$ was far higher than those of IAA, DIAA, and DIAcAm during chloramination (Fig. 2a). It is noted that other Cl-containing I-DBPs (e.g., $\mathrm{CHClI}_{2}, \mathrm{CHCl}_{2} \mathrm{I}, \mathrm{ClIAA}, \mathrm{ClIAcAm}$ ) were also detected $(5.87-22.39 \mathrm{nM})$. The concentrations of $\mathrm{CHI}_{3}$, IAA, DIAA and TIAA increased with increasing time, but the rates of increase were different for different compounds. At a reaction time of $12 \mathrm{~h}, 809 \mathrm{nM}$ $\mathrm{CHI}_{3}, 45 \mathrm{nM}$ IAA, $71 \mathrm{nM}$ DIAA, and $321 \mathrm{nM}$ TIAA were formed. By contrast, the concentration of DIAcAm reached a maximum of $90 \mathrm{nM}$ at $1 \mathrm{~h}$ and then decreased gradually with increasing time. This probably results from the rapid reaction of $\mathrm{HOI}$ (formed by the transformation of $I_{2}$ in water) with NOM to form DIAcAm, which was then further hydrolyzed to form DIAA (Fig. S3). Furthermore, it appears that NOM contained fast- and slow-reacting moieties, similar to those involved in $\mathrm{CHCl}_{3}$ formation [28]. 


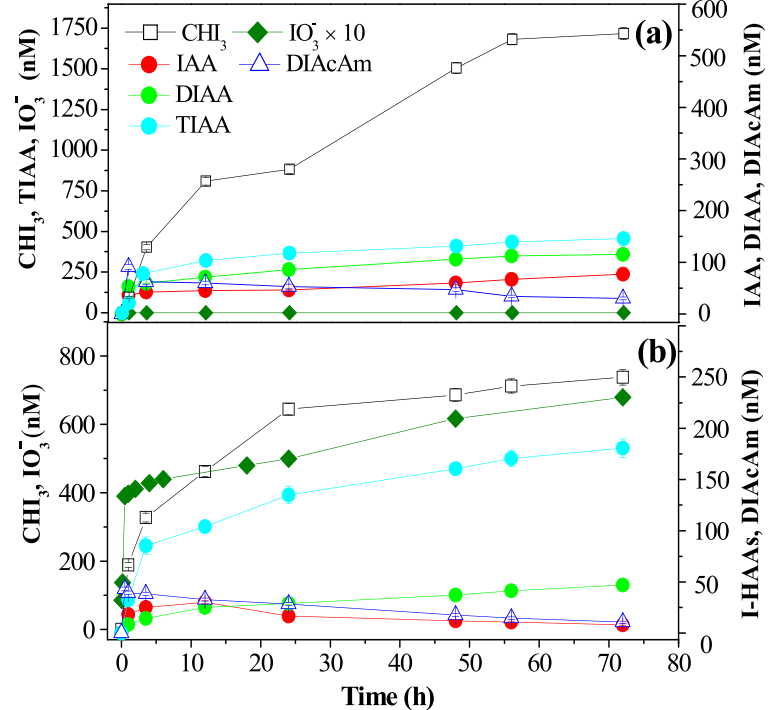

Fig. 2. Evolution of I-DBPs as a function of reaction time during chloramination (a) and chlorination (b). Experimental conditions: $\left[\mathrm{NH}_{2} \mathrm{Cl}\right]_{0}\left(\right.$ or $\left.\left[\mathrm{Cl}_{2}\right]_{0}\right)=100 \mu \mathrm{M}$, $\left[\mathrm{I}^{-}\right]_{0}=100 \mu \mathrm{M},[\mathrm{DOC}]_{0}=3.0 \mathrm{mg} / \mathrm{L}, 5 \mathrm{mM}$ phosphate buffer, $\mathrm{pH} 7.0,25^{\circ} \mathrm{C}$.

During chlorination, $\mathrm{CHI}_{3}, \mathrm{IO}_{3}{ }^{-}$, and TIAA showed the highest yields which reached a plateau after $2 \mathrm{~d}$ (Fig. 2b). The formation of DIAcAm was rapid and reached a maximum of $43.2 \mathrm{nM}$ at $30 \mathrm{~min}$, whereas the maximum concentration of IAA $(30.2 \mathrm{nM})$ occurred at $12 \mathrm{~h}$; both then decreased with extended time. The decrease of IAA concentration as a function of time suggests that it could be partially transformed into CIIAA in the presence of excess free chlorine, as demonstrated in Fig. S4. Therefore, the different IAA and DIAcAm concentrations formed during chloramination and chlorination were associated with their relative stabilities in the presence of free chlorine and $\mathrm{NH}_{2} \mathrm{Cl}$ (Fig. S4). For the stability of DIAcAm, a similar trend to that of DClAcAm was reported previously [29].

Overall, most of the measured I-DBPs (i.e., $\mathrm{CHI}_{3}, \mathrm{IAA}, \mathrm{DIAA}$, TIAA, and DIAcAm) showed higher concentrations during chloramination than during chlorination, while $\mathrm{IO}_{3}{ }^{-}$was only formed significantly during chlorination; which is consistent with previous studies $[13,30]$. This can be partly explained by free chlorine oxidizing $\mathrm{I}^{-}$to $\mathrm{IO}_{3}{ }^{-}$, which acted as a sink for $\mathrm{I}^{-}$, and thus decreased the formation of all other I-DBPs.

\subsection{Effect of $\mathrm{NH}_{2} \mathrm{Cl}$ dose on I-DBPs formation}

The effect of $\mathrm{NH}_{2} \mathrm{Cl}$ dosage (0.01-0.4 mM) on I-DBPs formation is shown in Fig. 3. The $\mathrm{CHI}_{3}$, TIAA, and DIAcAm concentrations significantly increased with increasing $\mathrm{NH}_{2} \mathrm{Cl}$ dose in the range of 0.01-0.1 mM, and then decreased with higher $\mathrm{NH}_{2} \mathrm{Cl}$ doses. In contrast, the IAA and DIAA concentrations increased progressively with increasing $\mathrm{NH}_{2} \mathrm{Cl}$ dose. The decrease in the $\mathrm{CHI}_{3}$, IAA, and DIAcAm concentrations at relatively high $\mathrm{NH}_{2} \mathrm{Cl}$ doses (0.1-0.4 mM) suggests that more $\mathrm{I}^{-}$could be directly oxidized to $\mathrm{IO}_{3}{ }^{-}$by free chlorine produced from $\mathrm{NH}_{2} \mathrm{Cl}$ hydrolysis, thus resulting in less organic IDBPs formation. The enhanced formation of free chlorine at high $\mathrm{NH}_{2} \mathrm{Cl}$ doses (0.1-0.4 mM) was also confirmed by the increased concentrations of $\mathrm{Cl}-\mathrm{DBPs}$ (e.g., $\mathrm{CHClI}_{2}$ and ClIAA, Fig. S5) formed in the reaction solution.

\subsection{Effect of $I^{-}$concentration on I-DBPs formation}

The effect of $\mathrm{I}^{-}$concentration on the formation of I-DBPs during chloramination is shown in Fig. 4. The concentrations of $\mathrm{CHI}_{3}$, TIAA, and DIAcAm increased significantly as the initial $\mathrm{I}^{-}$concen-

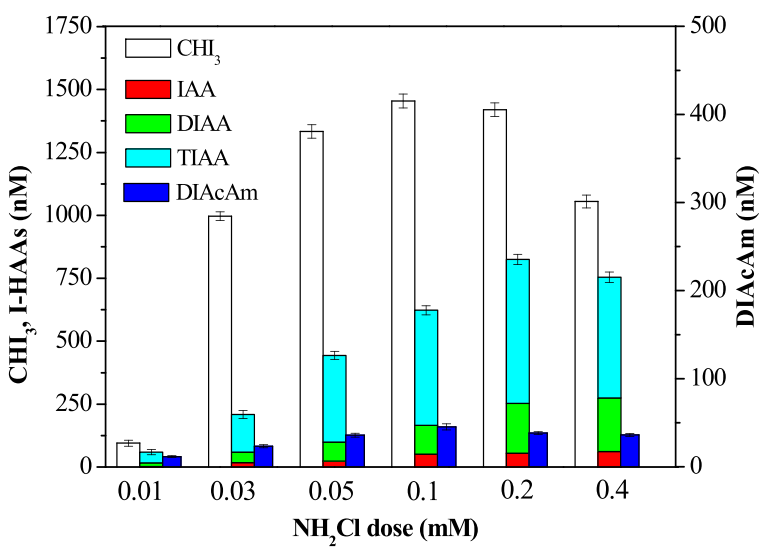

Fig. 3. Effect of $\mathrm{NH}_{2} \mathrm{Cl}$ dose on the formation of I-DBPs during chloramination. Experimental conditions: $\left[\mathrm{I}^{-}\right]_{0}=100 \mu \mathrm{M},[\mathrm{DOC}]_{0}=3.0 \mathrm{mg} / \mathrm{L}, 5 \mathrm{mM}$ phosphate buffer, $\mathrm{pH} 7.0,25^{\circ} \mathrm{C}$, reaction time $=3 \mathrm{~d}$.

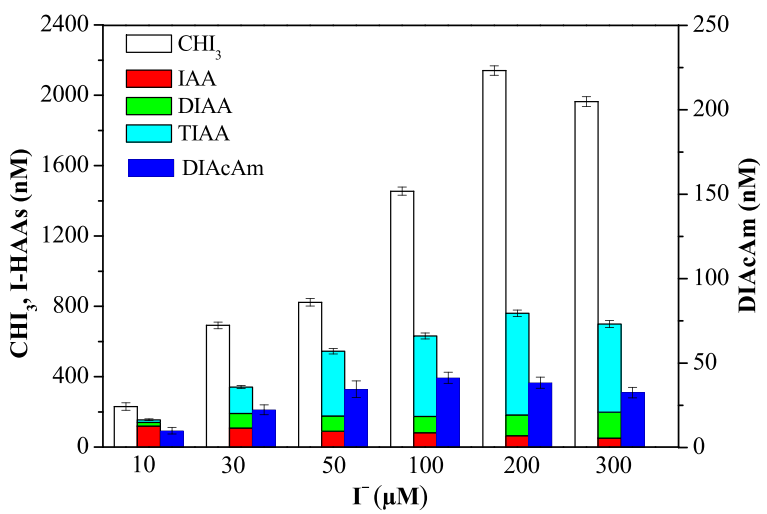

Fig. 4. Effect of $\mathrm{I}^{-}$concentration on the formation of I-DBPs during chloramination. Experimental conditions: $\left[\mathrm{NH}_{2} \mathrm{Cl}\right]_{0}=100 \mu \mathrm{M},[\mathrm{DOC}]_{0}=3.0 \mathrm{mg} / \mathrm{L}, 5 \mathrm{mM}$ phosphate buffer, $\mathrm{pH} 7.0,25^{\circ} \mathrm{C}$, reaction time $=3 \mathrm{~d}$.

tration increased from 10 to $200 \mu \mathrm{M}$, and then decreased slightly at a higher $\mathrm{I}^{-}$concentration (i.e., $300 \mu \mathrm{M}$ ). The DIAA concentration increased progressively with increasing $\mathrm{I}^{-}$concentration. Meanwhile, the IAA concentration decreased from 120 to $50 \mathrm{nM}^{\text {in }}$ this $\mathrm{I}^{-}$ concentration range. This result suggests the competition of excess $\mathrm{I}^{-}$for $\mathrm{NH}_{2} \mathrm{Cl}$ against NOM. Thus, although increasing $\mathrm{I}^{-}$concentration was likely to increase the production of $\mathrm{HOI} / \mathrm{I}_{2}$, a large excess of I $^{-}$(i.e., 200-300 $\mu \mathrm{M}$ ) could consume more $\mathrm{NH}_{2} \mathrm{Cl}$ and thus reduce the subsequent formation of I-DBPs. Furthermore, increasing $\mathrm{I}^{-}$ concentration could also induce the transformation of $\mathrm{HOI} / \mathrm{I}_{2}$ to $\mathrm{I}_{3}{ }^{-}$, which is relatively less reactive [31], thereby decreasing I-DBPs formation. Therefore, the molar ratio of $\mathrm{I}^{-}$to $\mathrm{NH}_{2} \mathrm{Cl}$ is critical for the iodine sink during chloramination.

\subsection{Effect of $\mathrm{pH}$ on I-DBPs formation}

Fig. 5 shows the formation of $\mathrm{CHI}_{3}$, IAA, DIAA, TIAA, and DIAcAm together with the consumption of $\mathrm{HOI} / \mathrm{I}_{2}$ during chloramination in the $\mathrm{pH}$ range of 5.0-9.0. $\mathrm{CHI}_{3}$ was at a minimum of $1.2 \mu \mathrm{M}$ at $\mathrm{pH} 5.0$, increased to a maximum of $1.6 \mu \mathrm{M}$ at $\mathrm{pH} 8.0$, and then decreased to $1.5 \mu \mathrm{M}$ at pH 9.0 (Fig. 5a). The concentrations of IAA, DIAA, TIAA, and DIAcAm decreased from $110,183,382$, and $90 \mathrm{nM}$ at $\mathrm{pH} 5.0$ to $58,72,364$, and $20 \mathrm{nM}$ at $\mathrm{pH} 9.0$, respectively, although the highest yields of IAA and TIAA were observed at $\mathrm{pH}$ 6.0. In general, acidic conditions favored the formation of I-HAAs, which is similar to the formation of the regulated THMs and HAAs at various $\mathrm{pH}$ values [32]. 


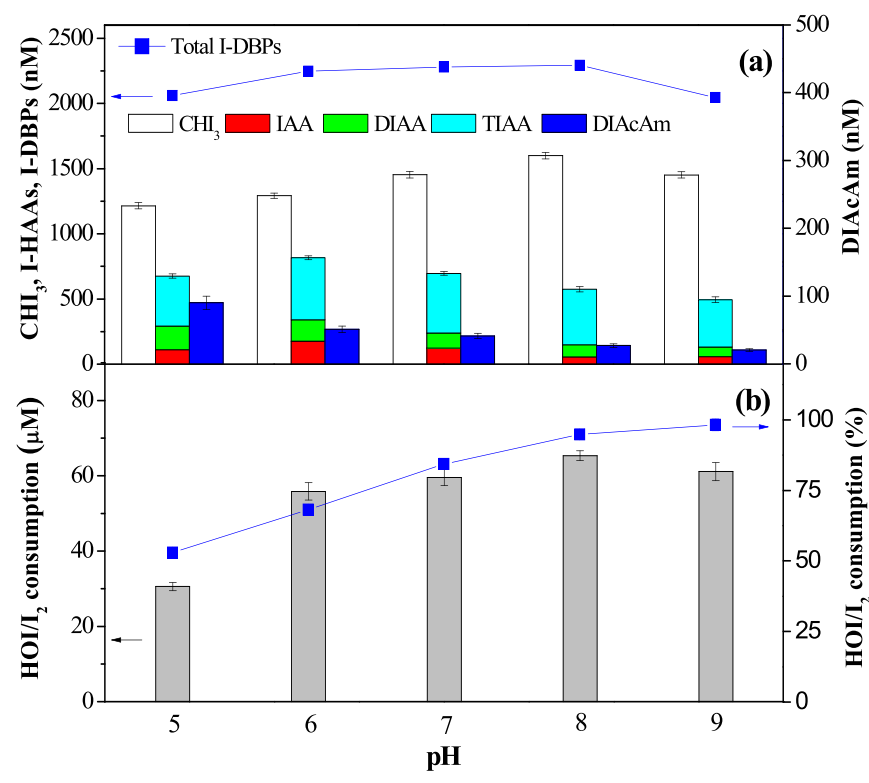

Fig. 5. Effect of $\mathrm{pH}$ on $\mathrm{I}-\mathrm{DBPs}$ formation and $\mathrm{HOI} / \mathrm{I}_{2}$ consumption during chloramination. Experimental conditions: $\left[\mathrm{NH}_{2} \mathrm{Cl}\right]_{0}=100 \mu \mathrm{M},\left[\mathrm{I}^{-}\right]_{0}=100 \mu \mathrm{M}$, $[\mathrm{DOC}]_{0}=3.0 \mathrm{mg} / \mathrm{L}, 5 \mathrm{mM}$ phosphate buffer, $25^{\circ} \mathrm{C}$, reaction time $=3 \mathrm{~d}$.

The pH-dependent change in the concentrations of I-DBPs can be mainly attributed to the following aspects:

First, the speciation of $\mathrm{HOI} / \mathrm{I}_{2}$ and the reactions between iodine and NOM are pH dependent [27]. Generally, at acidic pH conditions, $\mathrm{I}_{2}$ is the dominant species, while HOI becomes predominant at neutral to slightly alkaline conditions (Fig. S6). $\mathrm{I}_{3}{ }^{-}$was insignificant under our experimental conditions based on calculations using published equilibrium data [26,33]. Further experiments confirmed that the maximum $\mathrm{HOI} / \mathrm{I}_{2}$ consumption $(65.3 \mu \mathrm{M})$ occurred at $\mathrm{pH}$ 8.0 (Fig. 5b), where the dominant $\mathrm{HOI} / \mathrm{I}_{2}$ reacted rapidly with $\mathrm{NOM}$ resulting in the highest yield of total I-DBPs.

Second, $\mathrm{pH}$ affects the speciation of chloramines and the hydrolysis of $\mathrm{NH}_{2} \mathrm{Cl}$ to form free chlorine. Under acidic conditions, $\mathrm{NH}_{2} \mathrm{Cl}$ is hydrolyzed to form $\mathrm{HOCl}$ and $\mathrm{NH}_{3}$; as a result more free chlorine is released at $\mathrm{pH} 6.0$ than at $\mathrm{pH} 7.0-8.0$ [34]. Thus, the present experimental result was expected, because a small proportion of free chlorine in equilibrium with $\mathrm{NH}_{2} \mathrm{Cl}$ could play a significant role in I-DBPs formation.

Finally, $\mathrm{pH}$ also affects the stability of I-DBPs. Unlike THMs and HAAs, HAcAms usually undergo base-catalyzed decomposition. It was reported that HAcAms were unstable in aqueous solutions and could decompose quickly in alkaline conditions [29]. Our additional experiments on the stability of DIAcAm confirmed that its decomposition rate increased at higher $\mathrm{pH}$ values (Fig. S7). The pseudo-first-order rate constant $\left(k_{\text {obs }}^{\prime}\right)$ for hydrolysis of DIAcAm was $3.44 \times 10^{-2} \mathrm{~h}^{-1}$ at $\mathrm{pH} 9.0$, which is about twice that at $\mathrm{pH}$ $5.0\left(1.78 \times 10^{-2} \mathrm{~h}^{-1}\right)$. Therefore, the net DIAcAm concentration was lower at a higher $\mathrm{pH}$ value, and its highest concentration at $\mathrm{pH} 5.0$ could be explained by fast formation and slow hydrolysis at this $\mathrm{pH}$.

\subsection{Effect of NOM concentration on I-DBPs formation}

The effect of NOM concentration (expressed as DOC) on I-DBPs formation is shown in Fig. 6. The concentrations of $\mathrm{CHI}_{3}$ and TIAA increased significantly with increasing DOC concentration from 1.0 to $5.0 \mathrm{mg} / \mathrm{L}$, and then decreased at a higher DOC concentration (i.e., $7.0 \mathrm{mg} / \mathrm{L}$ ). The concentrations of DIAA and DIAcAm kept increasing over the studied NOM concentration range, whereas the IAA concentration remained nearly constant. The decrease in the $\mathrm{CHI}_{3}$

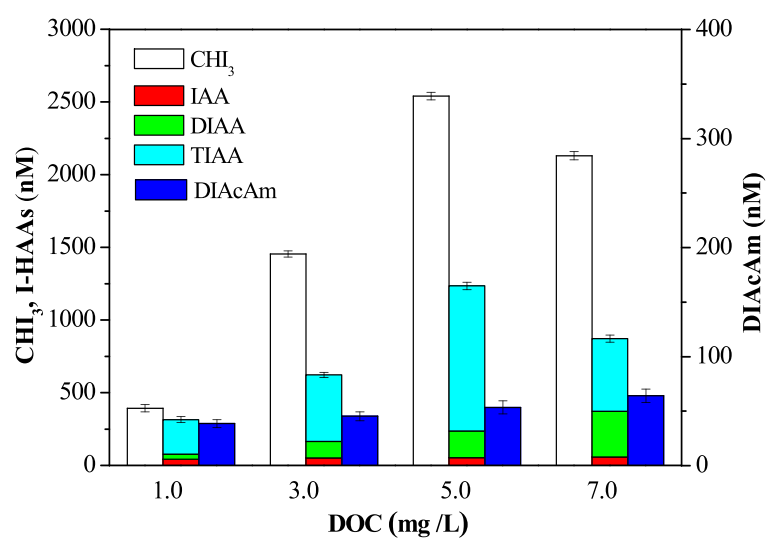

Fig. 6. Effect of NOM concentration on the formation of I-DBPs during chloramination. Experimental conditions: $\left[\mathrm{NH}_{2} \mathrm{Cl}\right]_{0}=100 \mu \mathrm{M},\left[\mathrm{I}^{-}\right]_{0}=100 \mu \mathrm{M}, 5 \mathrm{mM}$ phosphate buffer, $\mathrm{pH} 7.0,25^{\circ} \mathrm{C}$, reaction time $=3 \mathrm{~d}$.

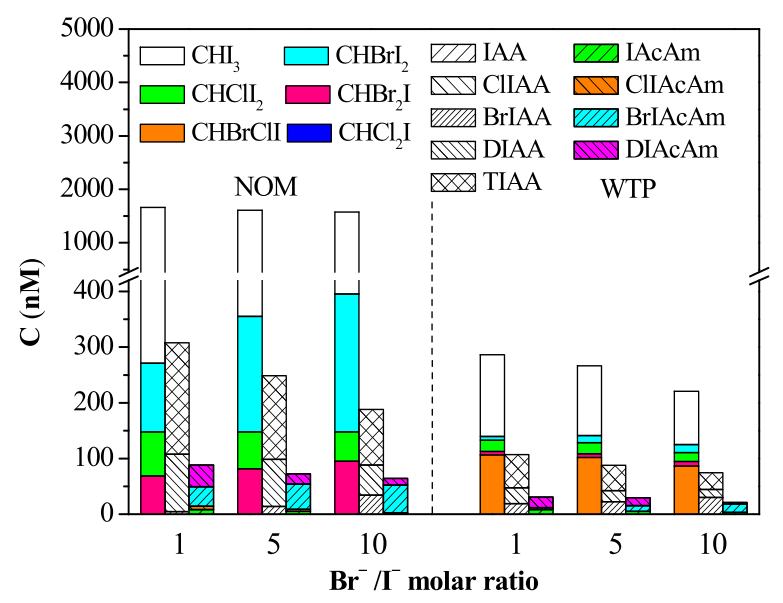

Fig. 7. Effect of $\mathrm{Br}^{-} / \mathrm{I}^{-}$molar molar ratio on the formation of I-DBPs during chloramination. Experimental conditions: $\left[\mathrm{NH}_{2} \mathrm{Cl}\right]_{0}=100 \mu \mathrm{M},\left[\mathrm{I}^{-}\right]_{0}=100 \mu \mathrm{M}, 5 \mathrm{mM}$ phosphate buffer, $\mathrm{pH} 7.0,25^{\circ} \mathrm{C}$, reaction time $=3 \mathrm{~d}$.

and TIAA concentrations at $7.0 \mathrm{mg} / \mathrm{L}$ DOC was attributable to the fact that triiodo-DBPs were less likely to be formed when excess reaction sites of NOM were available. In addition, a previous study reported that $\mathrm{NH}_{2} \mathrm{Cl}$ could act as a nitrogen source to some extent for DClAcAm formation, because MS analysis revealed that $>50 \%$ of the nitrogen present in dichloroacetonitile (DClAN) and DClAcAm came actually from $\mathrm{NH}_{2} \mathrm{Cl}$ [35]. Similarly, $\mathrm{NH}_{2} \mathrm{Cl}$ may also contribute nitrogen to the formation of DIAcAm.

\subsection{Effect of $\mathrm{Br}^{-} / \mathrm{I}^{-}$molar ratio on I-DBPs formation}

The molar ratio of $\mathrm{Br}^{-} / \mathrm{I}^{-}$can vary in source waters and thus affect I-DBPs formation. Fig. 7 shows the speciations and concentrations of I-THMs, I-HAAs and I-HAcAms during chloramination at various $\mathrm{Br}^{-} / \mathrm{I}^{-}$molar ratios in the synthetic (NOM) and WTP waters. Generally, increasing the $\mathrm{Br}^{-} / \mathrm{I}^{-}$molar ratio from 1 to 10 did not increase the total amount of I-DBPs, but changed the proportions of the mixed $\mathrm{Br}$ - and I-DBPs. For I-THMs, $\mathrm{CHI}_{3}$ was always the dominant species in the two waters, even when the concentration of $\mathrm{Br}^{-}$was 10 times that of $\mathrm{I}^{-}$. However, increasing $\mathrm{Br}^{-}$ concentration notably shifted the I-THMs towards those containing more bromine (e.g., $\mathrm{CHBrI}_{2}$ and $\mathrm{CHBr}_{2} \mathrm{I}$ ). For I-HAAs, TIAA was the dominant species, and the DIAA and TIAA concentrations decreased while the BrIAA concentration increased with increasing $\mathrm{Br}^{-} / \mathrm{I}^{-}$ molar ratio. Di-HAcAms (e.g., DIAcAm and BrIAcAm) accounted for the majority of I-HAcAms observed after chloramination of both 


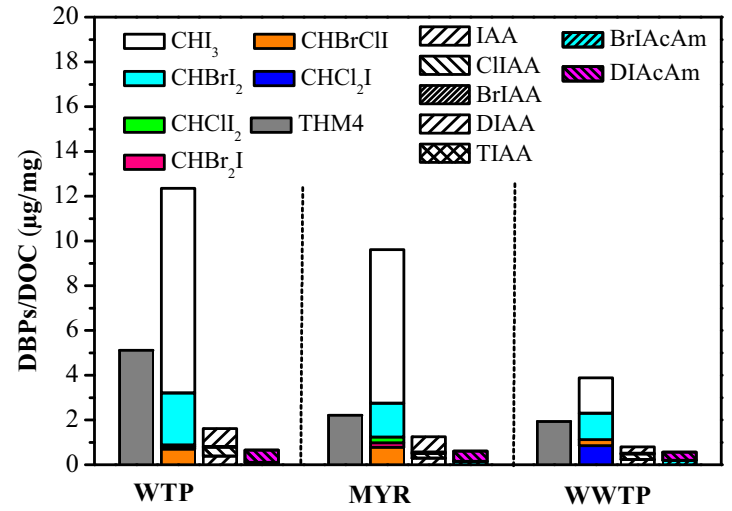

Fig. 8. Effect of water matrix on the formation of I-DBPs normalized by DOC concentration. Experimental conditions: $\left[\mathrm{NH}_{2} \mathrm{Cl}\right]_{0}=50 \mu \mathrm{M}$, spiked $\left[\mathrm{I}^{-}\right]_{0}=200 \mu \mathrm{g} / \mathrm{L}, 5 \mathrm{mM}$ phosphate buffer, $\mathrm{pH} 7.0,25^{\circ} \mathrm{C}$, reaction time $=3 \mathrm{~d}$.

waters. Moreover, the concentration of BrIAcAm increased substantially with increasing $\mathrm{Br}^{-} / \mathrm{I}^{-}$molar ratio. Overall, the formation patterns of I-DBPs in the two waters were quite similar. There are two reasons for the enhanced formation of bromine-substituting I-DBPs (e.g., BrIAA and BrIAcAm) at high $\mathrm{Br}^{-}$concentrations: (1) mixed interhalogen compounds (e.g., $\mathrm{ICl}, \mathrm{ICl}_{2}^{-} \mathrm{I}_{2} \mathrm{Cl}^{-}, \mathrm{IBr}, \mathrm{IBr}_{2}^{-}$, $\mathrm{I}_{2} \mathrm{Br}^{-}$) could be formed from HOI and $\mathrm{I}^{-}$in the presence of $\mathrm{Cl}^{-}$and $\mathrm{Br}^{-}$[36,37]; and (2) $\mathrm{NH}_{2} \mathrm{Cl}$ could oxidize a small amount of $\mathrm{Br}^{-}$to bromochloramine, which is more reactive toward NOM than $\mathrm{NH}_{2} \mathrm{Cl}$ [38].

\subsection{Effect of water matrix on I-DBPs formation}

To assess the effect of water matrix on I-DBPs formation, samples of various water sources spiked with $200 \mu \mathrm{g} / \mathrm{L} \mathrm{I}^{-}$were tested. Because of their different DOC contents, the concentrations of ITHMs, THM4, I-HAAs and I-HACAms were normalized by the DOC concentration (mg/L) (Fig. 8). For I-THMs, $\mathrm{CHI}_{3}$ and $\mathrm{CHBrI}_{2}$ were always the first and second abundant species for all the three waters, respectively. A considerable amount of $\mathrm{CHCl}_{2} \mathrm{I}$ was only detected in the WWTP water. For I-HAAs, DIAA was the most abun- dant I-HAA species, except for the WWTP water. For I-HAcAms, BrIAcAm and DIAcAm were two major species detected. The concentration of DIAcAm was always higher than that of BrIAcAm for all waters, which agrees with a previous study [39]. Overall, the DOCnormalized total yield of I-DBPs in the three real waters followed the descending order of WTP $>$ MYR $>$ WWTP, which was mainly attributable to their increasing DOC contents (Table 1 ).

The specific ultraviolet absorbance at $254 \mathrm{~nm}\left(\mathrm{SUVA}_{254}\right)$ has been widely used as an indicator of aromatic content and DBP formation potential of NOM [40], and a high $\mathrm{SUVA}_{254}$ value generally indicates a high aromatic content. From the limited data set in the present study, it appears that low-SUVA 254 NOM was more reactive in the formation of I-DBPs during chloramination than high-SUVA 254 NOM, which is consistent with previous findings $[41,42]$. In addition, the formation of the regulated THM4 showed a similar trend to that of I-THMs for various real waters after chloramination.

\subsection{I-DBPs formation during chloramination of model compounds}

To compare the reactivity of various organic precursors with iodine during chloramination, the speciation and yields of I-DBPs produced from 18 model compounds were evaluated. These compounds (i.e., amino acids, carboxylic acids, and aromatics), whose chemical structures and major characteristics are shown in Table $\mathrm{S} 1$, are present in the NOM structure and are known to react with free halogens. The highest I-DBPs/DOC value $(0.482 \%)$ was found with citric acid, followed by L-aspartic acid $(0.430 \%)$ and pyruvic acid (0.188\%) (Table 2). By contrast, chloramination of aromatic compounds contributed little to the formation of IDBPs (3.6-8.1 nM only), exhibiting very low I-DBPs/DOC values (0.0001-0.0011\%). This could probably be ascribed to the influence of electron-donating groups (e.g., methyl and hydroxyl) on the reactivity of aromatic compounds toward electrophilic substitutions [43]. The I-DBPs/DOC value was much lower for $p$-cresol $(0.0001 \%)$ than for other aromatic compounds, because para-arrangement of the phenolic group caused a more homogeneous distribution of electron density over all aromatic carbons. Taking into account the relationship between the I-DBPs/DOC and SUVA 254 values (Table

Table 2

Formation of I-DBPs during chloramination of 18 model compounds ${ }^{\mathrm{a}}$.

\begin{tabular}{|c|c|c|c|c|c|c|c|}
\hline Model compound & $\mathrm{CHI}_{3}(\mathrm{nM})$ & $\mathrm{IAA}(\mathrm{nM})$ & $\operatorname{DIAA}(\mathrm{nM})$ & TIAA(nM) & DIAcAm(nM) & I-DBPs(nM) & I-DBPs/DOC (\%) \\
\hline \multicolumn{8}{|l|}{ Amino acids } \\
\hline L-Aspartic acid & $362(19)^{b}$ & $\mathrm{ND}^{\mathrm{c}}$ & $17.9(1.3)$ & $327(16)$ & $2.8(0.3)$ & 709 & 0.430 \\
\hline L-Proline & $10.4(0.5)$ & ND & $6.4(0.3)$ & $14.1(1.5)$ & $0.6(0.3)$ & 17.4 & 0.004 \\
\hline Tyrosine & $4.8(0.5)$ & $2.2(0.5)$ & ND & ND & $14.8(1.0)$ & 21.8 & 0.012 \\
\hline Histidine & $21.1(0.8)$ & $21.5(1.1)$ & $10.6(0.6)$ & $21.3(1.5)$ & $2.9(0.3)$ & 56.1 & 0.011 \\
\hline Phenylalanine & $79.4(0.8)$ & ND & $20.5(1.0)$ & $52.2(3.0)$ & $4.5(0.3)$ & 104 & 0.014 \\
\hline Alanine & $26.9(0.5)$ & ND & $7.7(0.5)$ & $15.2(1.0)$ & $12.2(1.0)$ & 46.8 & 0.017 \\
\hline Glycine & $14.2(3.0)$ & ND & $3.5(0.3)$ & $10.3(0.2)$ & $1.3(0.6)$ & 29.3 & 0.016 \\
\hline \multicolumn{8}{|l|}{ Carboxylic acids } \\
\hline Salicylic acid & $10.9(2.8)$ & ND & $9.0(0.3)$ & $9.2(0.3)$ & $10.0(0.6)$ & 39.1 & 0.005 \\
\hline Citric acid & $1580(20)$ & $561(8)$ & $510(20)$ & $190(10)$ & $13.5(1.0)$ & 2854 & 0.482 \\
\hline Lactic acid & $23.9(3.8)$ & ND & $4.2(0.4)$ & $14.2(0.5)$ & $7.1(0.6)$ & 49.4 & 0.011 \\
\hline Propionic acid & $31.5(4.6)$ & ND & $12.2(0.6)$ & $27.9(0.5)$ & $4.8(0.3)$ & 76.4 & 0.026 \\
\hline Pyruvic acid & $397(23)$ & $108(4)$ & $0.6(0.3)$ & $269(0.2)$ & ND & 777 & 0.188 \\
\hline \multicolumn{8}{|c|}{ Aromatic compounds } \\
\hline Phenol & $3.0(0.9)$ & $1.6(0.5)$ & $3.5(0.6)$ & ND & ND & 8.1 & 0.0010 \\
\hline$m$-cresol & $5.6(0.5)$ & ND & $0.3(0.3)$ & $1.6(0.2)$ & ND & 7.5 & 0.0009 \\
\hline$p$-cresol & $3.8(0.3)$ & ND & ND & ND & ND & 3.8 & 0.0001 \\
\hline Catechol & $3.6(0.3)$ & ND & ND & ND & ND & 3.6 & 0.0007 \\
\hline Resorcinol & $4.1(0.5)$ & ND & ND & $2.3(0.3)$ & ND & 6.4 & 0.0011 \\
\hline Hydroquinone & $3.1(0.5)$ & ND & ND & $0.5(0.2)$ & ND & 3.6 & 0.0007 \\
\hline
\end{tabular}

a Experimental conditions: $\left[\mathrm{I}^{-}\right]_{0}=25 \mu \mathrm{M},\left[\mathrm{NH}_{2} \mathrm{Cl}\right]_{0}=50 \mu \mathrm{M}, 100 \mu \mathrm{M}$ each model compound, $5 \mathrm{mM}$ phosphate buffer, $\mathrm{pH} 7.0,25{ }^{\circ} \mathrm{C}$, reaction time $=3 \mathrm{~d}$.

b Mean (standard deviation), $n=3$.

c ND: not detected. 


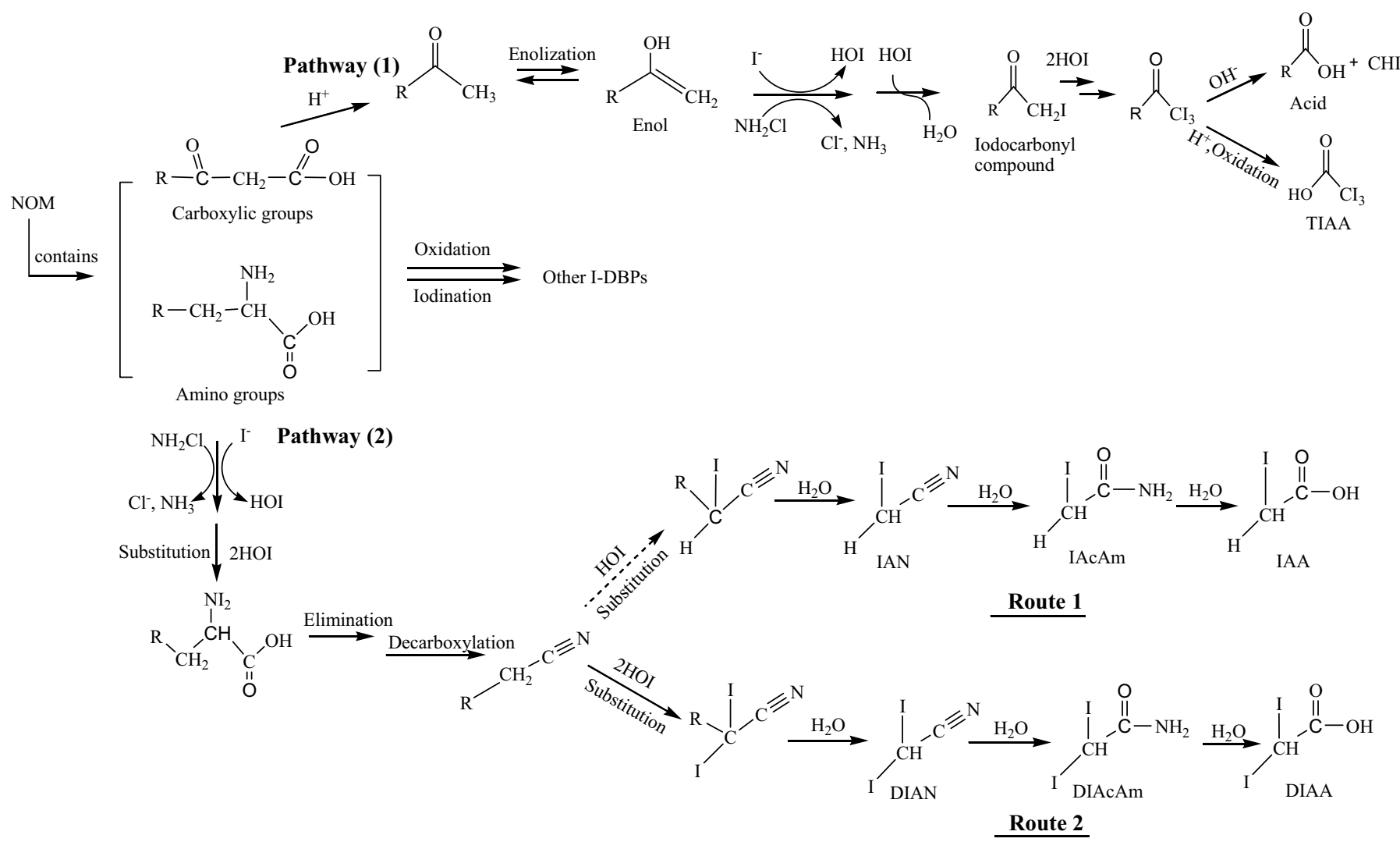

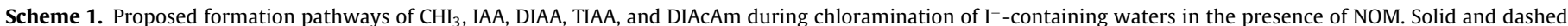
lines represent major and minor pathways, respectively.

S1), it is seen that the model compounds with low-SUVA 254 values (e.g., L-aspartic acid and citric acid) were generally more favorable in the formation of I-DBPs than those with high-SUVA 254 values (e.g., aromatics) during chloramination.

\subsection{Proposed pathways for I-DBPs formation from NOM}

NOM contains various types of carboxylic, aromatic, amino, and hydroxyl functional groups. Based on the present study and previous publications $[40,42,44,45]$, a reaction scheme involving two possible formation pathways for $\mathrm{CHI}_{3}$, IAA, DIAA, TIAA, and DIACAm is proposed (Scheme 1 ):

It is known that $\mathrm{NH}_{2} \mathrm{Cl}$ can quickly oxidize $\mathrm{I}^{-}$to $\mathrm{HOI} / \mathrm{I}_{2}$, but cannot further oxidize $\mathrm{HOI} / \mathrm{I}_{2}$ to $\mathrm{IO}_{3}{ }^{-}$due to its relatively weak oxidation potential. Under our experimental conditions (i.e., $\mathrm{pH}$ 7.0), HOI is the dominant form among various reactive iodine species (i.e., $\mathrm{I}_{2}, \mathrm{HOI}, \mathrm{OI}^{-}$) (Fig. S6). In Pathway (1), HOI cannot react directly with the carbonyl groups but only with their enolic forms, and either enolization or iodine addition to the enol can be rate-determining. Further iodination of an $\alpha$-iodomethyl carbonyl group proceeds in two sequential steps until the methyl has been completely converted to triiodomethyl $\left(-\mathrm{CHI}_{3}\right)$. Then, the triiodocarbonyl compound ( $\left.\mathrm{R}-\mathrm{CO}-\mathrm{Cl}_{3}\right)$ can either be hydrolyzed to $\mathrm{CHI}_{3}$ and a corresponding acid ( $\left.\mathrm{R}-\mathrm{COOH}\right)$ or be oxidized to TIAA if the $\mathrm{R}-$ is an oxidizable group. The detection of $\mathrm{CHI}_{3}$ (Fig. S8) and TIAA (Fig. S9) in this study could support this pathway.

In Pathway (2), there are two main routes for the formation of I-HAcAms: IAcAm (Route 1) and DIAcAm (Route 2). Trehy et al. [44] proposed that seven out of 20 basic amino acids during chlorination could form DClAcAm through a series of substitution, elimination, and decarboxylation reactions followed by further substitution. Similarly, iodine will substitute one hydrogen atom of the inter- mediate $\mathrm{R}-\mathrm{CH}_{2}-\mathrm{CN}$ to form $\mathrm{R}-\mathrm{CHI}-\mathrm{CN}$, whose hydrolysis yields iodoacetonitrile (IAN) (Route 1 ), which was frequently detected during chloramination of NOM and L-aspartic acid in this study (Fig. S8). Then, the sequential reactions of IAN with water lead to the formation of IACAm and IAA. It is noted that the IAN concentration increased with increasing time during chloramination, and the yield of IAcAm was much lower than that of DIAcAm because IAN is relatively more stable than diiodoacetonitrile (DIAN). Based on the quantitative structure-property relationship analysis model, the half-life of IAN is predicted to be $451 \mathrm{~d}$, which is longer than those of DIAN and triiodoacetonitrile [46]. Moreover, if HOI is abundant, iodine will substitute both hydrogen atoms of the intermediate R$\mathrm{CH}_{2}-\mathrm{CN}$ to form $\mathrm{R}-\mathrm{Cl}_{2}-\mathrm{CN}$, whose hydrolysis yields DIAN (Route 2). Unfortunately, DIAN could not be quantified in this study because of a lack of its authentic standard. The sequential reactions of DIAN with water lead to the formation of DIAcAm and DIAA. Our previous experiment has also demonstrated that IAcAm and DIAcAm could be hydrolyzed to IAA and DIAA, respectively (Fig. S3).

In addition to the I-DBPs, Cl-N-DBPs (e.g., DClAN, DClAcAm) were also detected during chloramination of NOM, although with much less concentrations $(1.9-2.1 \mu \mathrm{g} / \mathrm{L})$. It is also noted that besides the measured I-THMs, I-HAAs and I-HAcAms, the carboxylic and amino groups in the NOM structure were also likely to undergo oxidation and iodination reactions to form other unknown I-DBPs, which would increase the total organic iodine.

\section{Conclusions}

In reaction systems containing $\mathrm{NH}_{2} \mathrm{Cl}, \mathrm{I}^{-}$and $\mathrm{NOM}, \mathrm{CHI}_{3}, \mathrm{IAA}$, DIAA, TIAA, and DIACAm were the major species detected, and HOI and $\mathrm{I}_{2}$ were the reactive iodine species that contributed to the formation of I-DBPs. 
Solution $\mathrm{pH}$ showed a significant impact on the formation IDBPs in synthetic $\mathrm{I}^{-}$-containing waters. Increasing $\mathrm{Br}^{-} / \mathrm{I}^{-}$molar ratio from 1 to 10 did not increase the total amount of I-DBPs, but shifted their composition to more brominated species.

Among the 18 model compounds studied, L-aspartic acid, citric acid, and pyruvic acid exhibited the highest yields of I-DBPs during chloramination. The model compounds with low-SUVA 254 values were generally more favorable in the formation of I-DBPs than those with high-SUVA 254 values.

Potential pathways for the formation of I-THMs, I-HAAs, and I-HAcAms during chloramination were proposed in this study. However, it should be pointed out that the present conclusions are only drawn from laboratory water samples with high spikes of $\mathrm{I}^{-}$, and further measurements under more natural conditions (with respect to $\mathrm{Br}^{-}$and $\mathrm{I}^{-}$concentrations) are needed to assess the formation of I-DBPs during chloramination of natural waters.

\section{Acknowledgments}

This work was financially supported by the National Natural Science Foundation of China (51290281, 51221892, and 21367004), China Postdoctoral Science Foundation (2014M550096), and Guangxi Natural Science Foundation (2014GXNSFAA118284). We gratefully thank Dr. Urs von Gunten for his valuable suggestions to this manuscript.

\section{Appendix A. Supplementary data}

Supplementary data associated with this article can be found, in the online version, at http://dx.doi.org/10.1016/j.jhazmat.2016.08. 071.

\section{References}

[1] US EPA, National primary drinking water regulations: stage 2 disinfectants and disinfection byproducts rule, in: Federal Register, United States Environmental Protection Agency, Washington, DC, 2006, pp. 387-493.

[2] S.W. Krasner, H.S. Weinberg, S.D. Richardson, S.J. Pastor, R. Chinn, M.J. Sclimenti, G.D. Onstad, A.D. Thruston, Occurrence of a new generation of disinfection byproducts, Environ. Sci. Technol. 40 (2006) 7175-7185.

[3] E.H. Goslan, S.W. Krasner, M. Bower, S.A. Rocks, P. Holmes, L.S. Levy, S.A. Parsons, A comparison of disinfection by-products found in chlorinated and chloraminated drinking waters in Scotland, Water Res. 43 (2009) 4698-4706.

[4] Y. Bichsel, U. von Gunten, Oxidation of iodide and hypoiodous acid in the disinfection of natural waters, Environ. Sci. Technol. 33 (1999) 4040-4045.

[5] Y. Bichsel, U. von Gunten, Formation of iodo-trihalomethanes during disinfection and oxidation of iodide containing waters, Environ. Sci. Technol. 34 (2000) 2784-2791.

[6] M.J. Plewa, E.D. Wagner, S.D. Richardson, A.D. Thruston, Y.T. Woo, A.B. McKague, Chemical and biological characterization of newly discovered lodoacid drinking water disinfection byproducts, Environ. Sci. Technol. 38 (2004) 4713-4722.

[7] R.C. Hansson, M.J. Henderson, P. Jack, R.D. Taylor, Iodoform taste complaints in chloramination, Water Res. 21 (1987) 1265-1271.

[8] G.Y. Ding, X.R. Zhang, A picture of polar iodinated disinfection byproducts in drinking water by (UPLC/)ESI-tqMS, Environ. Sci. Technol. 43 (2009) 9287-9293.

[9] W.H. Chu, N.Y. Gao, D.Q. Yin, S.W. Krasner, M.R. Templeton, Trace determination of 13 haloacetamides in drinking water using liquid chromatography triple quadrupole mass spectrometry with atmospheric pressure chemical ionization, J. Chromatogr. A 1235 (2012) 178-181.

[10] S.D. Richardson, F. Fasano, J.J. Ellington, F.G. Crumley, K.M. Buettner, J.J. Evans, B.C. Blount, L.K. Silva, T.J. Waite, G.W. Luther, Occurrence and mammalian cell toxicity of iodinated disinfection byproducts in drinking water, Environ. Sci. Technol. 42 (2008) 8330-8338.

[11] M.J. Plewa, E.D. Wagner, M.G. Muellner, K.M. Hsu, S.D. Richardson, Comparative mammalian cell toxicity of N-DBPs and C-DBPs, in: Disinfection By-Products in Drinking Water, ACS Symposium Series, American Chemical Society : Washington, DC, 2008, pp. 36-50 (Chapter 3).

[12] M.J. Plewa, Y. Kargalioglu, D. Vankerk, R.A. Minear, E.D. Wagner, Mammalian cell cytotoxicity and genotoxicity analysis of drinking water disinfection by-products, Environ. Mol. Mutagen. 40 (2002) 134-142
[13] S.E. Duirk, C. Lindell, C.C. Cornelison, J. Kormos, T.A. Ternes, M. Attene-Ramos, J. Osiol, E.D. Wagner, M.J. Plewa, S.D. Richardson, Formation of toxic iodinated disinfection by-products from compounds used in medical imaging, Environ. Sci. Technol. 45 (2011) 6845-6854.

[14] M.J. Plewa, M.G. Muellner, S.D. Richardson, F. Fasanot, K.M. Buettner, Y.T Woo, A.B. Mckague, E.D. Wagner, Occurrence, synthesis, and mammalian cell cytotoxicity and genotoxicity of haloacetamides: an emerging class of nitrogenous drinking water disinfection byproducts, Environ. Sci. Technol. 42 (2008) 955-961

[15] N.K.V. Leitner, J. Vessella, M. Dore, B. Legube, Chlorination and formation of organoiodinated compounds: the important role of ammonia, Environ. Sci. Technol. 32 (1998) 1680-1685.

[16] J. Criquet, S. Allard, E. Salhi, C.A. Joll, A. Heitz, U. von Gunten, Iodate and iodo-trihalomethane formation during chlorination of iodide-containing waters: role of bromide, Environ. Sci. Technol. 46 (2012) 7350-7357.

[17] S. Allard, J. Tan, C.A. Joll, U. von Guntenit, Mechanistic study on the formation of $\mathrm{Cl} / \mathrm{Br}$-/I-trihalomethanes during chlorination/chloramination combined with a theoretical cytotoxicity evaluation, Environ. Sci. Technol. 49 (2015) $11105-11114$

[18] T. Ye, B. Xu, Y.L. Lin, C.Y. Hu, L. Lin, T.Y. Zhang, N.Y. Gao, Formation of iodinated disinfection by-products during oxidation of iodide-containing waters with chlorine dioxide, Water Res. 47 (2013) 3006-3014.

[19] W.H. Guo, Y.C. Shan, X. Yang, Factors affecting the formation of iodo-trihalomethanes during oxidation with chlorine dioxide, J. Hazard. Mater. 264 (2014) 91-97.

[20] G.H. Hua, D.A. Reckhow, Comparison of disinfection byproduct formation from chlorine and alternative disinfectants, Water Res. 41 (2007) 1667-1678.

[21] T. Ye, B. Xu, Y.L. Lin, C.Y. Hu, S.J. Xia, L. Lin, S.A. Mwakagenda, N.Y. Gao, Formation of iodinated disinfection by-products during oxidation of iodide-containing water with potassium permanganate, J. Hazard. Mater. 241 (2012) 348-354

[22] I. Kristiana, H. Gallard, C. Joll J.P. Croué, The formation of halogen-specific TOX from chlorination and chloramination of natural organic matter isolates, Water Res. 43 (2009) 4177-4186.

[23] G.H. Hua, D.A. Reckhow, J. Kim, Effect of bromide and iodide ions on the formation and speciation of disinfection byproducts during chlorination, Environ. Sci. Technol. 40 (2006) 3050-3056.

[24] P.J. Vikesland, K. Ozekin, R.L. Valentine, Monochloramine decay in model and distribution system waters, Water Res. 35 (2001) 1766-1776.

[25] APHA, AWWA, W.E.F, Standard Methods for the Examination of Water and Wastewater, 20th edition, APHA Publication Office, Washington, D.C, 1998.

[26] J.C. Ianni, Kintecus V4.55, http://kintecus.com/newpage17.htm (accessed on August 20 2016)

[27] J.A. Warner, W.H. Casey, R.A. Dahlgren, Interaction kinetics of $I_{2}(a q)$ with substituted phenols and humic substances, Environ. Sci. Technol. 34 (2000) 3180-3185.

[28] X. Yang, C. Shang, P. Westerhoff, Factors affecting formation of haloacetonitriles, haloketones, chloropicrin and cyanogen halides during chloramination, Water Res. 41 (2007) 1193-1200.

[29] W.H. Chu, N.Y. Gao, Y. Deng, Stability of newfound nitrogenous disinfection by-products haloacetamides in drinking water, Chinese. J. Org. Chem. 29 (2009) 1569-1574.

[30] Z. Wang, B. Xu, Y.L. Lin, C.Y. Hu, F. X. Tian, T.Y Zhang N.Y Gao, A comparison of iodinated trihalomethane formation from iodide and iopamidol in the presence of organic precursors during monochloramination, Chem. Eng. J. 257 (2014) 292-298

[31] Y.P. Lin, M.P. Washburn, R.L. Valentine, Reduction of lead oxide $\left(\mathrm{PbO}_{2}\right)$ by iodide and formation of iodoform in the $\mathrm{PbO}_{2} / \mathrm{I}^{-} / \mathrm{NOM}$ system, Environ. Sci. Technol. 42 (2008) 2919-2924.

[32] H. Pourmoghaddas, A.A. Stevens, Relationship between trihalomethanes and haloacetic acids with total organic halogen during chlorination, Water Res. 29 (1995) 2059-2062.

[33] A.J. Bard, R. Parsons, J. Jordan, Standard Potentials in Aqueous Solution, Marcel Dekker, New York, 1985.

[34] J. Morris, R. Isaac, A critical review of kinetic and thermodynamic constants for the aqueous chlorine-ammonia system, in: R.L. Jolley, W.A. Brungs, J.A. Cotruvo, R.B. Cumming, J.S. Mattice, V.A. Jacobs (Eds.), Water Chlorination: Environmental Impact and Health Effects, 4, Ann Arbor Science Publishsers, Michigan, 1983, pp. 49-62.

[35] H. Huang, Q.Y. Wu, H.Y. Hu, W.A. Mitch, Dichloroacetonitrile and dichloroacetamide can form independently during chlorination and chloramination of drinking waters, model organic matters, and wastewater effluents, Environ. Sci. Technol. 46 (2012) 10624-10631

[36] Y.L. Wang, J.C. Nagy, D.W. Margerum, Kinetics of hydrolysis of iodine monochloride measured by the pulsed-accelerated-flow method, J. Am. Chem. Soc. 111 (1989) 7838-7844.

[37] R.C. Troy, M.D. Kelley, J.C. Nagy, D.W. Margerum, Non-metal redox kinetics: iodine monobromide reaction with iodide ion and the hydrolysis of $\mathrm{IBr}$, Inorg. Chem. 30 (1991) 4838-4845

[38] J.M. Symons, R. Xia, G.E. Speitel, A.C. Diehl, C.J. Hwang, S.W. Krasner, S.E. Barrett, Factors Affecting Disinfection By-product Formation During Chloramination, in: U.AWWA Research Foundation, American Water Works Association (Ed.), 1998

[39] W.H. Chu, N.Y. Gao, D.Q. Yin, S.W. Krasner, Formation and speciation of nine haloacetamides, an emerging class of nitrogenous DBPs, during chlorination or chloramination, J. Hazard. Mater. 260 (2013) 806-812. 
[40] D.A. Reckhow, P.C. Singer, R.L. Malcolm, Chlorination of humic materials: byproduct formation and chemical interpretations, Environ. Sci. Technol. 24 (1990) 1655-1664.

[41] G.H. Hua, D.A. Reckhow, Characterization of disinfection byproduct precursors based on hydrophobicity and molecular size, Environ. Sci. Technol. 41 (2007) 3309-3315.

[42] W.H. Chu, N.Y. Gao, D.Q. Yin, S.W. Krasner, W.A. Mitch, Impact of UV/ $\mathrm{H}_{2} \mathrm{O}_{2}$ pre-oxidation on the formation of haloacetamides and other nitrogenous disinfection byproducts during chlorination, Environ. Sci. Technol. 48 (2014) 12190-12198.
[43] H. Gallard, S. Allard, R. Nicolau, U. von Gunten, J.P. Croué, Formation of iodinated organic compounds by oxidation of iodide-containing waters with manganese dioxide, Environ. Sci. Technol. 43 (2009) 7003-7009.

[44] M.L. Trehy, R.A. Yost, C.J. Miles, Chlorination by-products of amino-acids in natural-waters, Environ. Sci. Technol. 20 (1986) 1117-1122.

[45] R.C. Fuson, B.A. Bull, The haloform reaction, Chem. Rev. 15 (3) (1934) 275-309

[46] B.Y. Chen, Hydrolytic stabilities of halogenated disinfection byproducts: review and rate constant quantitative structure-property relationship analysis, Environ. Eng. Sci. 28 (2011) 385-394. 